\title{
Analisis The Whalen Seven Steps Strategic Divisi Komunikasi dan Marketing Jakarta Smart City pada Aplikasi Jakarta Kini
}

\section{Analysis of The Whalen 7 Strategic Steps Of The Communication And Marketing Department of Jakarta Smart City On The Jakarta Kini (Jaki) Application}

\author{
Farahdinta Destanti a ,Uljanatunnisab, ${ }^{\text {, }}$, Lusia Handayanic \\ a, b, cUniversitas Pembangunan Nasional "Veteran" Jakarta, Jalan RS Fatmawati, Jakarta, Indonesia \\ email: *uljanatunnisa@upnvj.ac.id
}

Menerima 18 Oktober 2021, Revisi 15 November 2021, Diterima 6 Desember 2021, Online 17 Desember 2021

\begin{abstract}
ABSTRAK
Kehidupan manusia modern tidak dapat dilepaskan dari kemajuan teknologi karena dampaknya yang memberikan kemudahan dalam beraktivitas, seperti kemudahan dalam memperoleh informasi dari media. Pemanfaatan media ini tidak hanya dilakukan oleh individu, tetapi juga oleh institusi seperti Jakarta Smart City (JSC). Jakarta Smart City hadir dalam bentuk aplikasi yang bernama JAKI (Jakarta Kini) dengan berbagai fitur yang bertujuan untuk mempermudah kehidupan masyarakat yang tinggal ataupun beraktivitas di Jakarta. Untuk memperkenalkan aplikasi JAKI ke masyarakat, divisi komunikasi dan marketing JSC menerapkan dua dari tiga konsep marketing public relations (PR), yaitu pull and pass strategy. Hasilnya, JSC berhasil mencapai target jumlah pengguna aplikasi Jakarta Kini sebanyak satu juta orang. Tujuan penelitian ini adalah untuk mengkaji kunci keberhasilan dari strategi pull and pass yang dijalankan oleh Divisi Komunikasi dan Marketing untuk aplikasi JAKI. Analisis penelitian ini menggunakan konsep the Whalen 7 Steps Strategic dengan metode penelitian studi kasus dan wawancara sebagai teknik pengumpulan data. Hasil penelitian menunjukkan bahwa strategi pull and pass yang dijalankan oleh Divisi Komunikasi dan Marketing sesuai dengan konsep the Whalen 7 Steps Strategic, seperti pemanfaatan media sosial, website, press release, pemuka masyarakat, email blast, JSC talks, dan pameran.
\end{abstract}

Kata kunci : Marketing Public Relations, Strategi Pull and Pass, Jakarta Smart City, Aplikasi JAKI

\section{ABSTRACT}

Modern life can not be separated from technological advancement because of its impact that provides convenience in activities, such as easy access to information from media. Media is not only used by individuals, but also by institutions such as Jakarta Smart City (JSC). Jakarta Smart City launched an application called JAKI (Jakarta Kini) with varied features in it to facilitate the lives of people living or working in Jakarta. To introduce the application to the public, the communications and marketing division of Jakarta Smart City applied two of three marketing public relations strategies, namely pull and pass strategy. The strategy has proven successful in reaching one million users of JAKI application. The purpose of this study was to analyse the pull and pass strategy carried out by the communications and marketing divisions for the JAKI application. The Whalen Seven Steps Strategic Planning Process was the conceptual framework used in this case study, which collected data from interviews. The study showed that the implementation of pull and pass marketing strategy by the Communication and Marketing Department complied with the Whalen 7 Steps Strategic Planning Process, as found in the use of social media, website, press release, community leader, email blast, JSC Talks, and Exhibition.

Keyword : Jakarta Smart City, JAKI Application, Marketing Public Relations, Pull and Pass Strategy

84 | Vol.10 No.2 /November 2021 http://doi.org/10.31504/komunika.v10i2.4406.

(C) 2021 Jurnal Komunika:Jurnal Komunikasi dan Informatika. Semua hak cipta dilindungi undang-undang. 


\section{PENDAHULUAN}

Kehidupan manusia modern tidak dapat dilepaskan dari kemajuan teknologi. Kemudahan yang dihadirkan oleh kemajuan teknologi telah mempermudah aktivitas manusia, misalnya dalam berkomunikasi ataupun memperoleh informasi melalui media (Ngafifi, 2014). Saat ini, tidak hanya individu saja yang berusaha memanfaatkan keberadaan media, tetapi juga lembaga. Terdapat sejumlah lembaga yang memanfaatkan media bahkan membentuk platform media sendiri, di antaranya adalah Badan Perpustakaan Nasional (Perpusnas), BMKG dan Pemerintah Provinsi (Pemprov) DKI Jakarta. Saat ini, Jakarta Smart City yang berada di bawah struktur Dinas Komunikasi, Informatika, dan Statistik Pemprov DKI Jakarta telah memiliki aplikasi bernama JAKI.

JAKI (Jakarta Kini) merupakan aplikasi layanan dalam genggaman yang diluncurkan oleh Pemprov DKI Jakarta sejak September 2019 dengan tujuan untuk mempermudah hidup masyarakat yang menetap ataupun beraktivitas di Jakarta. Untuk memanfaatkan kemajuan teknologi ini, Jakarta Smart City menerapkan digitalisasi layanan publik melalui aplikasi yang bernama JAKI (Jakarta Kini) yang dapat diakses melalui smartphone. Seperti dikatakan oleh Yudistira selaku Kepala BLUD Jakarta Smart City, JAKI merupakan SuperApp yang dikembangkan oleh Pemprov DKI yang mengintegrasikan berbagai layanan publik dan informasi resmi dari berbagai dinas di Jakarta. Aplikasi JAKI diperuntukkan bagi seluruh masyarakat DKI Jakarta dan masyarakat yang beraktivitas di DKI Jakarta dan sekitarnya.

Di tengah situasi wabah Covid-19 saat ini yang menghalangi masyarakat untuk dapat berkonsultasi dengan tenaga medis secara langsung, JAKI menghadirkan solusi melalui sejumlah fitur pendukung, di antaranya adalah Jakarta Tanggap Covid-19. Hingga akhir tahun 2020, tercatat total downloader aplikasi JAKI baru mencapai 920.000 pengguna dari target sebanyak 1.000 .000 . Hal ini menunjukkan bahwa terdapat target Jakarta Smart City yang belum terpenuhi pada tahun 2020. Namun, pada bulan Februari 2021, laman Instagram Jakarta Smart City @jsclounge mengabarkan bahwa JAKI berhasil mencapai jumlah satu juta pengguna. Ke depannya, JAKI memiliki target meningkatkan layanan digital berdasarkan kebutuhan. Hal ini diharapkan dapat memudahkan serta memenuhi kebutuhan masyarakat melalui satu aplikasi.

Untuk mencapai jumlah target tersebut, Jakarta Smart City melakukan kegiatan marketing public relations agar keberadaannya lebih dikenal masyarakat. Hal ini dipandang perlu mengingat masih terdapat masyarakat yang belum mengetahui keberadaan aplikasi JAKI ini. Upaya untuk memperkenalkan JAKI ke masyarakat menjadi tanggung jawab dari divisi komunikasi dan marketing di Jakarta Smart City. Divisi komunikasi bertugas melakukan sosialisasi konsep, informasi dan kebijakan terkait JSC ke berbagai pihak dalam format yang mudah dipahami dengan media yang tepat. Adapun divisi marketing bertugas melaksanakan kegiatan pemasaran produk kepada pihak swasta, seperti Gojek, Bukalapak, Grab, Shopee, Duithape, Sekolahmu, Tokopedia dan lainnya. Kedua divisi ini bekerja sama untuk memperkenalkan aplikasi JAKI. Berdasarkan pengamatan, hanya ada dua konsep yang diterapkan dalam marketing PR JSC, yakni dengan menerapkan strategi pull dan pass. Namun, kedua strategi tersebut membuahkan hasil yang signifikan dengan hadirnya konten informatif dan variatif dengan design menarik di media sosial secara rutin untuk masyarakat. Lalu ada pula forum diskusi rutin bernama JSC Talks yang mengundang pembicara yang berkontribusi di aplikasi JAKI dan staf JSC. Meskipun hanya menerapkan dua konsep, JAKI berhasil mengukir prestasi sebagai juara pertama aplikasi di sektor publik pada ajang Karya Terpilih Indonesia Entrepreneur (idenTIK) 2020 dari Kementerian Komunikasi dan Informatika RI dan pada ajang Innovative Government Award 2020 sebagai SuperApp yang memenuhi kebutuhan warga Jakarta, khususnya saat pandemi Covid-19. Berdasarkan latar belakang tersebut, menarik untuk dikaji lebih jauh tentang strategi yang digunakan oleh Divisi Komunikasi dan Divisi Marketing Jakarta Smart City untuk aplikasi JAKI sehingga bisa mencapai target jumlah pengguna yang ditetapkan. Selain itu, penelitian ini merupakan tindak lanjut dari temuan penelitian terdahulu, tentang perlunya penelitian baru pada bidang marketing PR dengan tujuan untuk memperkaya referensi serta mengambil sudut pandang yang berbeda terkait marketing PR (Messakh \& Fuady, 2017). Maka rumusan masalah pada penelitian ini adalah bagaimana strategi pull and pass yang dijalankan oleh Divisi Komunikasi dan Marketing Jakarta Smart City pada aplikasi JAKI?

\section{Government Public Relations}

Government public relations atau humas pemerintah adalah fungsi manajemen yang sah, yang membantu menjadikan badan, departemen, dan entitas publik lainnya tanggap terhadap warga (Suprawoto, 2018). Humas pemerintah juga bertugas untuk menerima masukan dari warganya. Berdasarkan Keputusan Kementerian Komunikasi dan Informatika Nomor 371/KEP/M.KOMINFO/8/2007, humas pemerintah adalah aktivitas yang dilakukan individu atau lembaga yang melaksanakan fungsi manajemen pada bidang komunikasi dan informasi kepada publik pemangku kepentingan dan sebaliknya. Berbeda dengan humas swasta, publik dalam humas pemerintah tidak hanya pemangku kepentingan tetapi juga seluruh warga negara dan masyarakat yang lebih luas.

Terdapat beberapa perbedaan antara humas pemerintah dan umum, humas pemerintah berada di bawah lembaga pemerintah, sehingga fokus perhatiannya tidak hanya stakeholder tetapi juga seluruh warga negara dan 
masyarakat. Sementara itu, fokus perhatian humas secara umum hanya publik dan stakeholder. Perbedaan lainnya terletak pada tugas yang disandang. Pada humas pemerintah, tugasnya bukan hanya membentuk citra lembaga, melainkan juga memberikan pelayanan informasi dan komunikasi kepada masyarakat dan tidak dibebani tugas untuk menjual produk. Sementara itu, humas secara umum biasanya diberi tugas untuk membentuk citra perusahaan dan mendukung kinerja penjualan produk (Anggoro, 2008).

Sedangkan aktvitas humas pemerintah, dapat dijelaskan sebagai berikut (Suprawoto, 2018):

a. Humas pemerintah merupakan fungsi manajemen

Humas pemerintah menjalankan fungsi mediator dalam manajemen pemerintahan.

b. Humas pemerintah merupakan aktivitas lembaga negara

Oleh karena itu, dalam melaksanakan kegiatannya, humas pemerintah sedang mengemban tugas negara.

c. Melaksanakan fungsi informasi dan komunikasi

Komunikasi dan informasi merupakan dua garda terdepan dalam manajemen pemerintahan. Tugas utama humas pemerintah adalah memberikan pelayanan kepada masyarakat, menginformasikan kegiatan serta program pemerintah, dan memenuhi hak masyarakat.

d. Sasaran humas pemerintah tidak hanya publik dan pemangku kepentingan

Lain dengan humas swasta yang memiliki sasaran berupa publik dan pemangku kepentingan, humas pemerintah memiliki sasaran lainnya, yaitu masyarakat atau warga sebagai pemilik atau pembayar pajak.

\section{Marketing Public Relations}

Marketing dan PR bak air dan minyak, keduanya memiliki orientasi yang berbeda namun perbedaan keduanya disatukan dengan nama marketing PR. Marketing PR merupakan gabungan antara strategi, marketing, dan public relations. Menurut Harris dalam (Ali, 2017), marketing PR adalah sebuah proses perencanaan dan evaluasi program yang mendorong kinerja penjualan yang dilakukan melalui komunikasi informasi dan kesan yang kredibel yang dapat menghubungkan perusahaan, produk dengan kebutuhan serta perhatian pelanggan. Tujuan marketing PR secara langsung mendukung promosi perusahaan serta pembentukan citra. Penggabungan keduanya akan menjadi soft selling action. Kotler dalam (Ruslan, 2010) mengungkapkan peranan marketing PR secara garis besar, yakni:

a. Mendukung program perusahaan seperti upaya mencapai tujuan perusahaan dalam berkompetisi

b. Menumbuhkembangkan kesadaran konsumen terhadap suatu produk

c. Membangun kepercayaan konsumen terhadap citra perusahaan atau manfaat dari produk yang ditawarkan/digunakan

d. Menekan biaya promosi iklan komersial

e. Meningkatkan pelayanan kepada konsumen, termasuk upaya mengatasi keluhan untuk mencapai kepuasan pihak pelanggan

f. Membantu mengampanyekan peluncuran produk baru sekaligus merencanakan perubahan posisi produk yang lama

g. Membina dan mempertahankan citra perusahaan atau produk barang dan jasa, baik dari segi kuantitas maupun kualitas pelayanan yang diberikan kepada konsumen

Selain itu, definisi lain dari marketing PR menurut Kotler dan Keller dalam (Wijaya dkk., 2012) adalah kegiatan yang dipandang untuk memperoleh ruang editorial berbayar dalam media cetak dan penyiaran untuk mempromosikan suatu produk atau jasa. Menurutnya, dimensi MPR tersebut meliputi Publications, Events, News, Sponsorship, Speeches, Public Service Activities, Identity Media. Marketing PR awalnya lebih dikenal dengan publisitas, namun saat ini MPR memiliki fungsi lebih dari itu, di antaranya adalah:

a. Mendukung peluncuran produk

b. Membantu repositioning produk

c. Memopulerkan kategori produk tertentu

d. Memengaruhi kelompok sasaran tertentu

e. Membela produk yang sedang berada dalam masalah

f. Membangun citra perusahaan sehingga dapat menaikkan citra produknya

Konsep PR yang terdapat dalam marketing PR melahirkan strategi untuk menciptakan opini publik.

\section{Strategi Marketing Public Relations}

Strategi marketing PR dilakukan dengan memelihara hubungan baik dengan publiknya. Hal ini akan memunculkan citra positif perusahaan, sehingga konsumen sebagai publiknya akan lebih mudah menerima dan mengonsumsi produk yang dihasilkan oleh perusahaan (Nugrahani, 2006). Dalam kegiatan marketing PR terdapat tiga strategi, yakni: 
a. Push Strategy

Strategi ini bertujuan untuk mempromosikan suatu produk yang ditujukan kepada distributor, dealer, sales

force dan retailers. Misalnya dengan menjual barang secara langsung dan mengatur point of sale untuk meningkatkan visibilitas dengan bentuk pertukaran, baik berupa uang ataupun barang.

b. Pull Strategy

Strategi ini bertujuan untuk menarik pelanggan melalui berbagai media dan ditujukan kepada konsumen akhir, sehingga konsumen akan datang dengan sendirinya untuk menggunakan produk tersebut. Biasanya, strategi ini dilakukan melalui media event/visit, publikasi produk, pameran expo, sampling, survei, newsletter, iklan layanan masyarakat, websites, dan lainnya.

c. Pass Strategy

Strategi ini bertujuan untuk menciptakan opini publik yang menguntungkan. Target ini ditujukan kepada pemerintah, LSM, konsumen sebagai masyarakat dan pembentuk opini. Biasanya, strategi ini dilakukan melalui kerja sama dengan aktivis, pemuka masyarakat, program peduli, pergelaran event dan sponsorship.

Salah satu karakteristik pesan dalam marketing PR adalah Proactive Marketing Public Relations. Karakteristik ini umumnya ditemukan pada saat pengenalan dan revisi produk, tujuannya adalah memberi tambahan informasi, menaikkan nilai berita, dan memunculkan kredibilitas produk. Keunggulan produk melalui Proactive Marketing PR yang dibentuk melalui editorial atau penyiar ialah lebih kredibel. Salah satu perannya adalah melakukan publisitas sebagaimana periklanan dan penjualan, misalnya melalui news release, konferensi pers, foto, dan film. Menurut Shimp dalam (Ali, 2017), terdapat tiga bentuk publisitas PR yang berorientasi pada pemasaran, yaitu :

a. Product Release

Product Release adalah upaya mengumumkan produk, memberikan informasi mengenai fitur dan manfaat produk serta memberitahu informasi tambahan.

b. Executive Statement Release

Executive Statement Release adalah news release mengenai CEO dan eksekutif perusahaan lainnya terkait berita yang relevan dengan perusahaan. Hal ini memiliki tingkat kredibilitas yang signifikan. Misalnya, seperti komentar tentang isu lingkungan, pemberitahuan tentang program baru yang diluncurkan, dan lainnya

c. Feature Article

Feature Article adalah penjelasan rinci mengenai produk atau program yang layak diberitakan yang ditulis oleh perusahaan PR untuk segera dipublikasikan atau ditayangkan, baik secara cetak ataupun melalui media online.

\section{The Whalen Seven Steps Strategic}

The Whalen 7 Steps Strategic menurut Harris dalam (Messakh \& Fuady, 2017) merupakan konsep marketing PR yang terdiri dari 7 perencanaan strategis yang terdapat dalam perencanaan korporat yang baik. Tahapan ini juga mampu memastikan bahwa tujuan yang sedang dikejar sudah berfokus pada target yang tepat serta memudahkan manajemen dalam membandingkan dan menilai masing-masing elemen kegiatan. Penelitian terdahulu yang dilakukan oleh (Messakh \& Fuady, 2017) dengan judul Perencanaan Marketing Public Relations Program Net Citizen Journalism PT. Net Mediatama Indonesia menerapkan konsep marketing PR yang terdiri dari 7 tahapan. Konsep tersebut juga berhasil mencapai target yang hendak dicapai dan mampu meningkatkan awareness serta jumlah pengguna aplikasi Net Citizen Journalism. Penerapan the Whalen 7 Steps Strategic pada penelitian ini sesuai dengan Kotler dalam (Rahmawati dkk., 2019) terkait peranan marketing public relations dalam mencapai tujuan perusahaan. Penggunaan konsep ini dapat diterapkan ke dalam rencana pemasaran untuk program promosi individual, rencana periklanan, rencana hubungan masyarakat, pameran dagang, hingga brosur. Tujuh langkah tersebut terdiri dari :

a. Analisis Situasi (Situation Analysis)

Proses ini digunakan untuk menganalisis situasi dan mendefinisikan apa yang terjadi pada suatu organisasi atau perusahaan hingga mendapatkan suatu keputusan tentang tindakan yang diterapkan oleh organisasi dalam upaya menyelesaikan permasalahan tersebut.

b. Menetapkan Tujuan (Setting Objectives)

Proses menetapkan tujuan ini harus spesifik dan dapat diukur. Tujuan ini terbagi menjadi dua, yaitu tujuan jangka pendek dan jangka panjang. Tujuan jangka pendek (output) merupakan pencapaian perusahaan dalam bentuk angka, sedangkan tujuan jangka panjang (outcome) mengarah kepada perubahan perilaku yang diharapkan oleh perusahaan.

c. Mendefinisikan Strategi (Defining Strategy)

Strategi merupakan perencanaan dari bagaimana upaya marketing public relations tersebut akan dijalankan. Penyusunan strategi disusun dengan menyesuaikan anggaran perusahaan, sehingga PR dapat membuat perencanaan yang tepat. 
d. Mengidentifikasi Target (Identifying the Targets)

Mengidentifikasi target dilakukan untuk mengetahui siapa saja yang akan dijangkau dalam penyusunan strategi yang dibuat. Hal ini dapat dilakukan berdasarkan kondisi geografis (tempat tinggal), demografis (usia, pendapatan, jenis kelamin, dan lainnya), hingga psikografis (kelas ekonomi, kepribadian, atau preferensi gaya hidup).

e. Membuat Pesan (Creating the Message)

Pembuatan pesan ini dilandasi oleh insight mendalam untuk mengetahui minat publik serta hal-hal yang membuat mereka mengambil keputusan akan suatu produk. Selain itu, pesan juga disesuaikan dengan bentuk strategi yang akan diambil. Pesan dapat dibuat secara menarik dan persuasif.

f. Mengidentifikasi Taktik (Identifying the Tactics)

Merupakan metode yang diimplementasikan untuk mencapai tujuan marketing PR. Taktik merupakan hal yang penting lantaran menjadi dasar dari kesuksesan penerapan MPR. Penerapan taktik dalam MPR dapat dilakukan dengan memberikan penghargaan, menerbitkan buku atau majalah, menyelenggarakan pameran, seminar, interview, hingga video news release.

g. Mengevaluasi Keefektifan Rencana (Evaluating)

Kegiatan untuk mengukur keberhasilan yang dilihat dari terwujudnya beberapa aspek perencanaan di atas. Selain itu, evaluasi juga berfungsi sebagai bahan perbaikan dari kegiatan yang telah direncanakan.

\section{METODE}

Pada penelitian ini, peneliti menggunakan pendekatan kualitatif. Metode yang digunakan pada penelitian ini adalah studi kasus. Menurut Depikbud dalam (Hardani dkk, 2020), metode penelitian studi kasus meliputi individu, kelompok, lembaga dan masyarakat. Peneliti menggunakan metode studi kasus agar dapat memahami strategi MPR yang dijalankan divisi komunikasi dan marketing dari Jakarta Smart City untuk aplikasi yang dimilikinya, yaitu aplikasi layanan publik JAKI.

\section{Teknik Pengumpulan Data}

Dalam penelitian ini, peneliti menggunakan data primer dan juga data sekunder:

1. Data Primer

Data primer adalah data yang diperoleh langsung dari sumbernya tanpa melalui perantara. Dalam penelitian ini, peneliti melakukan wawancara untuk memperoleh data yang dibutuhkan. Wawancara dilakukan dengan manajer divisi komunikasi, manajer divisi marketing dan juga staf dari masing-masing divisi terkait di Jakarta Smart City.

2. Data Sekunder

Data sekunder adalah data yang diperoleh melalui perantara, tidak diperoleh secara langsung dari sumbernya. Data sekunder menjadi data pendukung dalam menyusun penelitian. Data ini dapat diperoleh dari:

a. Dokumentasi, seperti buku, majalah, media online, dan lainnya

b. Studi kepustakaan, seperti dengan membaca buku, jurnal, catatan, dan lainnya

c. Teknik penentuan informan

\section{Teknik Penentuan Informan}

Teknik penentuan informan yang digunakan adalah purposive sampling. Penentuan informan dilakukan agar data yang didapatkan kredibel dan sesuai dengan informasi yang dibutuhkan oleh informan. Kriteria tersebut di antaranya merupakan karyawan aktif Jakarta Smart City dan terlibat langsung pada kegiatan MPR yang dilaksanakan. Pada penelitian ini terdapat dua informan, yaitu manajer divisi komunikasi dan manajer divisi marketing Jakarta Smart City. Keduanya dipilih lantaran mereka adalah orang yang terlibat langsung serta bertanggung jawab terhadap pelaksanaan kegiatan marketing PR Jakarta Smart City.

\section{Teknik Analisis Data}

Analisis data pada penelitian kualitatif termasuk proses yang sulit dan memerlukan kerja keras. Bogdan menyatakan dalam (Ahyar dkk, 2020) bahwa analisis data adalah proses mencari dan menyusun secara sistematis data yang diperoleh dari hasil wawancara, catatan lapangan, dan bahan-bahan lain, sehingga mudah dipahami dan temuannya dapat dihasilkan secara induktif sesuai dengan data yang didapatkan di lapangan. Teknik analisis data pada penelitian ini menggunakan model interaktif dari Miles dan Huberman (Hamzah, 2020). Menurut model ini, analisis harus dilakukan secara interaktif dan berlangsung terus menerus sampai data yang diperoleh jenuh. Aktivitas dalam analisis data meliputi data reduction, data display, dan conclusion drawing/verification. 


\section{HASIL DAN PEMBAHASAN}

Berdasarkan hasil wawancara yang telah dilakukan, penulis menganalisis bagaimana Divisi Komunikasi dan Divisi Marketing Jakarta Smart City menerapkan strategi pull and pass marketing PR untuk aplikasi JAKI. Menurut Harris dalam (Ali, 2017), strategi pull merupakan strategi yang bertujuan untuk menarik pelanggan melalui berbagai media dan ditujukan kepada konsumen akhir, sehingga diharapkan konsumen akan datang dengan sendirinya untuk menggunakan produk tersebut. Strategi pull juga mampu membangun hubungan baik dan tidak memerlukan kampanye iklan yang besar karena masyarakat telah mengetahui produknya dan mengetahui apa yang mereka harapkan dari produk tersebut (Bazaza, 2020). Hal ini rutin dilakukan oleh Divisi Komunikasi dengan memanfaatkan media sosial, seperti Instagram, Twitter, Facebook dan Tiktok untuk memublikasikan konten yang dibuat hingga rutin mengirim press release ke media. Sementara itu, Divisi Marketing melakukan email blast kepada masyarakat untuk menyosialisasikan layanan Jakarta Smart City, yaitu aplikasi JAKI. Pada kegiatan email blast, Divisi Marketing melakukan sosialisasi dengan mengirimkan email kepada masyarakat yang datanya telah diperoleh saat pameran yang diselenggarakan oleh Divisi Komunikasi dan Marketing. Kegiatan email blasting tersebut dilakukan untuk memperkenalkan produk Jakarta Smart City, termasuk juga aplikasi JAKI. Adapun strategi pass ialah strategi untuk memunculkan opini publik yang baik oleh individu ataupun grup (Ediraras, dkk., 2013). Kegiatan ini dapat dilakukan melalui kerja sama dengan aktivis, pemuka masyarakat, program peduli, gelaran event dan sponsorship. Strategi ini dilakukan oleh Divisi Komunikasi dan Marketing dengan melibatkan Gubernur DKI Jakarta, Anies Baswedan, serta menyelenggarakan event, baik online berupa webinar bernama JSC Talks maupun offline dalam bentuk pameran.

\section{STRATEGI PULL \& PASS DIVISI KOMUNIKASI DAN MARKETING JAKARTA SMART CITY}

\section{Media Sosial}

Pemanfaatan media sosial dilakukan oleh Divisi Komunikasi dalam menyosialisasikan aplikasi JAKI. Media sosial yang dimanfaatkan di antaranya adalah Twitter, Facebook, Instagram, LinkedIn, TikTok dan kanal Youtube. Divisi Komunikasi rutin membuat konten berupa foto, infografik, dan video. Dalam satu hari, Divisi Komunikasi memiliki target posting sebanyak 3-4 post di setiap platform. Saat ini, masing-masing konten yang diunggah di berbagai platform media sosial mereka adalah konten yang sama. Artinya, mereka hanya cukup membuat satu konten utama lalu disebar di berbagai platform lain. Konten yang diunggah oleh Divisi Komunikasi selalu berangkat dari permasalahan masyarakat yang berkaitan dengan program Pemprov DKI Jakarta ataupun aplikasi JAKI itu sendiri. Misalnya saja, saat ini sedang marak perihal pendaftaran vaksinasi Covid-19. Dalam proses pembuatan konten, Divisi Komunikasi juga memperhatikan pesan yang digunakan. Mereka menggunakan pesan yang mudah dipahami tetapi tetap sesuai dengan kaidah. Selain pesan, waktu juga menjadi hal yang diperhatikan oleh Divisi Komunikasi. Jam unggah yang ditetapkan adalah pada pukul 09:00, 12:00, 17:00, dan 19:00. Divisi Komunikasi juga memanfaatkan prime time untuk mengunggah konten, yakni pada pukul 19:00 dan 17:00. Oleh karena itu, pada waktu tersebut Divisi Komunikasi akan mengunggah konten-konten utama supaya dapat menjangkau masyarakat yang lebih luas. Hal ini sesuai dengan pernyataan Papasolomou (2012) bahwa konten media sosial yang menarik, membina masyarakat, dan mendorong keterlibatan masyarakat, baik yang bersifat formal maupun informal, banyak disukai oleh pengguna media sosial. Dalam membuat konten, setiap pekan Divisi Komunikasi melakukan brainstorming. Selanjutnya, gagasan yang muncul dalam brainstorming tersebut akan dieksekusi berdasarkan peran tiap bagian di Divisi Komunikasi, dimintakan approval dan kemudian dipublikasi. Setelah itu, dilakukan rapat dengan agenda evaluasi sebagai bahan perbaikan untuk konten berikutnya.

\section{Website}

Selain media sosial, Divisi Komunikasi juga memanfaatkan website sebagai sarana sosialisasi. Pada laman smartcity.jakarta.go.id, Divisi Komunikasi sering mengunggah konten dalam bentuk artikel yang biasanya berkaitan dengan program Pemerintah Provinsi DKI Jakarta. Misalnya, artikel mengenai langkah mendaftar vaksinasi melalui aplikasi JAKI, artikel mengenai anjuran untuk memperhatikan PPKM selama Ramadan dan libur lebaran, artikel terkait webinar JSC Talks yang telah terlaksana dan masih banyak lagi.

\section{Press Release}

Selain pemanfaatan media sosial digital, Divisi Komunikasi JSC juga rutin mengirim press release ke media cetak yang akan dijadikan bahan pemberitaan oleh media. Pemberitaan tersebut nantinya juga turut menyebarkan informasi lebih luas lagi ke masyarakat. Divisi Komunikasi umumnya memanfaatkan berbagai platform gratis lantaran belum ada anggaran khusus untuk advertising di media cetak. Meskipun begitu, hal ini menunjukkan ketepatan strategi yang digunakan oleh Divisi Komunikasi dan Marketing JSC. Menurut Gani dalam (Khopipah, 
2019), marketing PR merupakan kegiatan yang mampu meminimalisasi pengeluaran perusahaan, baik dalam bentuk elektronik ataupun cetak.

\section{Pemuka Masyarakat}

Strategi lain yang digunakan oleh Divisi Komunikasi adalah dengan melibatkan pemuka masyarakat untuk menyosialisasikan aplikasi JAKI. Gubernur DKI Jakarta, Anies Baswedan, sebagai orang nomor satu di Jakarta dilibatkan untuk membantu menyosialisasikan aplikasi JAKI. Cara ini dianggap paling efektif dan memberikan dampak yang paling signifikan terhadap jumlah pengguna aplikasi JAKI. Peran pemuka masyarakat seperti Gubernur DKI Jakarta dalam menyosialisasikan aplikasi JAKI sangat besar sehingga aplikasi ini dapat dimanfaatkan oleh masyarakat.

\section{Email Blast}

Strategi ini dilaksanakan oleh Divisi Marketing yang bertugas untuk memperluas relasi dan penjualan dengan memanfaatkan email blast sebagai strategi untuk menjangkau masyarakat luas dalam menyebarkan informasi mengenai aplikasi JAKI. Pengiriman pesan langsung melalui email menjadi salah satu metode terpenting dalam pemasaran secara langsung (Leppäniemi, 2008). Divisi Marketing mengirim email kepada kurang lebih 9000 users dalam kegiatan sosialisasi tersebut. Data pengguna tersebut diperoleh pada saat pelaksanaan sosialisasi secara offline, yaitu dalam bentuk pameran yang dilakukan pada tahun 2016-2019.

\section{Jakarta Smart City Talks (JSC Talks)}

Strategi berikutnya merupakan strategi yang dijalankan sebagai kegiatan lintas divisi antara divisi komunikasi dan marketing berupa event webinar online yang bernama Jakarta Smart City Talks atau yang biasa dikenal dengan sebutan JSC Talks. JSC Talks merupakan event online yang diadakan sebagai sarana sosialisasi yang bertujuan untuk mengedukasi serta memberikan informasi dengan mengangkat topik hangat atau permasalahan di DKI Jakarta yang dikaitkan dengan berbagai fitur di aplikasi JAKI. Selain itu, pada event ini dapat dihadirkan narasumber dari berbagai kalangan ataupun dari pihak internal Jakarta Smart City yang dianggap kompatibel untuk menjadi pembicara. Kegiatan JSC Talks ini gratis bagi masyarakat umum, terutama masyarakat DKI Jakarta dengan rentang usia 18-45 tahun. Adapun berbagai tema yang pernah dibahas dalam JSC Talks meliputi penanganan Covid-19, jumlah wifi gratis yang tersebar di DKI Jakarta dan fitur-fitur yang terdapat dalam aplikasi JAKI.

Pada kegiatan lintasdivisi ini, kedua divisi melakukan peran yang hampir serupa, yakni pembahasan mengenai topik yang akan diangkat dan permasalahan teknis. Secara khusus, Divisi Marketing bertugas menyiapkan narasumber, teknis pendaftaran dan teknis zoom meeting. Kemudian, Divisi Komunikasi akan melakukan pemetaan tema yang akan diangkat, mencari narasumber, membuat TOR, pertanyaan, bahan publikasi hingga Youtube streaming dan zoom meeting. Dengan melaksanakan event edukatif secara gratis, hal ini memunculkan image positif di mata masyarakat karena tidak semua BLUD (Badan Layanan Unit Daerah) menyelenggarakannya (Rahman, dkk., 2020).

\section{Pameran}

Strategi terakhir yang dilaksanakan oleh kedua divisi tersebut sebagai kegiatan lintasdivisi adalah pameran. Pameran sebelumnya dilaksanakan pada 2019 lalu, tetapi karena pandemi melanda, kini pameran belum bisa dilaksanakan kembali. Kegiatan pameran ini bertujuan untuk menyosialisasikan aplikasi JAKI kepada masyarakat. Untuk memunculkan daya tarik, kedua divisi tersebut menggunakan layar monitor untuk menampilkan gambar dan menyediakan booth.

Kegiatan pameran ini dilakukan dengan menggandeng instansi pemerintah lain dan event organizer. Peran Divisi Marketing pada pameran ini adalah bertanggung jawab melakukan koordinasi acara tersebut secara keseluruhan, seperti melakukan pengawasan terhadap design yang dibuat oleh Divisi Komunikasi hingga melakukan pengawasan terhadap tata letak booth pameran. Sementara itu, Divisi Komunikasi memberikan support berupa penyediaan materi sosialisasi, materi publikasi dan design yang akan digunakan pada saat mendirikan booth.

\section{THE WHALEN SEVEN STEPS STRATEGIC}

Secara umum, strategi pull dan pass yang diterapkan tidak luput dari tujuh tahap perencanaan atau yang biasa dikenal dengan The Whalen 7 Steps Strategic yang dikemukakan oleh Harris. The Whalen 7 Steps Strategic menurut Harris dalam (Messakh \& Fuady, 2017) merupakan konsep marketing PR yang terdiri dari 7 perencanaan strategis korporat yang baik, yaitu analisis situasi, menetapkan tujuan, mendefinisikan strategi, mengidentifikasi target, membuat pesan, mengidentifikasikan taktik, dan mengevaluasi.

a. Analisis situasi 
Menurut Harris dalam (Messakh \& Fuady, 2017), proses ini digunakan untuk menganalisis situasi dari sebuah organisasi atau perusahaan hingga mendapatkan solusi untuk menyelesaikan permasalahan yang ada. Dalam hal ini, peneliti melihat bahwa analisis situasi telah dilakukan oleh Divisi Komunikasi dalam pembuatan konten media sosial. Konten tersebut dibuat oleh Divisi Komunikasi berdasarkan situasi terkini di masyarakat, misalnya menyangkut permasalahan di Ibukota atau program Pemprov DKI Jakarta. Selain itu, Divisi Komunikasi juga memperhatikan insight social media, seperti followers yang aktif, sebelum membuat konten di berbagai platform.

b. Menetapkan tujuan

Hasil wawancara menunjukkan bahwa kedua divisi tersebut melakukan beragam kegiatan untuk menyosialisasikan aplikasi JAKI kepada masyarakat, baik melalui publikasi di media sosial, rutin mengirim press release, menggunakan figur Gubernur sebagai agen sosialisasi, menyelenggarakan pameran, mengirim email blasting, hingga mengadakan event online berupa webinar. Dengan output berupa foto atau video, media sosial dapat menjangkau masyarakat dengan rentang usia 18-34 tahun, sedangkan melalui press release, jangkauan masyarakat bisa lebih luas lagi. Penggunaan email blast juga dapat menyasar masyarakat secara langsung melalui email, sedangkan penyelenggaraan pameran membantu sosialisasi secara langsung melalui booth. Sementara itu, webinar membantu menyosialisasikan serta mengedukasi masyarakat dengan mengundang berbagai narasumber yang kompatibel di bidangnya.

c. Mendefinisikan strategi

Berdasarkan wawancara dengan narasumber, Divisi Komunikasi dan Divisi Marketing menjalankan pull and pass strategy. Pull strategy meliputi pemanfaatan sosial media seperti Instagram, Twitter, Facebook dan Tiktok untuk memublikasikan konten yang dibuat, serta rutin mengirim press release. Adapun Divisi Marketing melakukan email blast kepada masyarakat untuk menyosialisasikan aplikasi JAKI. Selain pull strategy, pass strategy juga diterapkan di antaranya dengan melibatkan pemuka masyarakat seperti Anies Baswedan sebagai Gubernur DKI Jakarta yang turut merespons di media sosial pribadinya, penyelenggaraan pameran dan webinar. Strategi yang digunakan oleh kedua divisi tersebut mencakup pembuatan konten di media sosial, press release, melakukan email blast, pelibatan pemuka masyarakat, dan penyelenggaraan event online dan offline.

d. Mengidentifikasi target

Target dari pembuatan konten media sosial adalah seluruh followers dari Instagram @jsclab, target dari JSC Talks adalah masyarakat umum dan masyarakat Jakarta dengan usia 18-45 tahun, sedangkan target dari penyelenggaraan pameran adalah seluruh pengunjung pameran.

e. Membuat pesan

Divisi Komunikasi membuat pesan yang menarik dengan menggunakan bahasa yang mudah dipahami. Berdasarkan pengamatan peneliti, umumnya karakteristik pesan yang digunakan oleh Divisi Komunikasi ialah proactive marketing public relations. Menurut Shimp dalam (Ali, 2017), karakteristik pesan ini bertujuan memberi tambahan informasi, meningkatkan nilai berita, dan memunculkan kredibilitas produk. Salah satu perannya adalah dengan melakukan publisitas, seperti news release, foto, film, hingga konferensi pers. Hal ini sesuai dengan fungsi dari Divisi Komunikasi sebagai Public Relations dari Jakarta Smart City yang menyampaikan pesan informatif di berbagai platform. Selain itu, Divisi Komunikasi juga menjalankan peran untuk melakukan publisitas seperti foto, news release, artikel dan lainnya melalui website yang dimiliki. Dengan kemampuannya sebagai PR, tentu mereka mampu menyajikan pesan secara lebih menarik dan berdampak besar (Kitchen, 2015). Namun, tidak semua jenis publisitas dijalankan oleh Divisi Komunikasi, misalnya konferensi pers yang sejauh ini belum terlaksana karena dirasa belum diperlukan.

f. Mengidentifikasi taktik

Berdasarkan definisi Harris dalam (Messakh \& Fuady, 2017), taktik dapat berupa pemberian penghargaan, penerbitan majalah, penyelenggaraan pameran, seminar, hingga video news release. Berdasarkan hasil penelitian dan definisi di atas, penulis menganalisis bahwa taktik yang diterapkan di antaranya adalah pameran dan webinar. Namun, menurut Raedi, taktik yang digunakan dalam pembuatan konten ialah ATM, yang merupakan singkatan dari Amati, Tiru dan Modifikasi. Dengan demikian, pembentukan konten selalu didasarkan pada proses pengamatan mengenai tipe konten yang disukai oleh masyarakat, kemudian ditindaklanjuti dengan proses pembuatan konten dengan metode meniru dan modifikasi.

g. Evaluasi

Kegiatan evaluasi rutin dilakukan dalam bentuk rapat evaluasi mingguan dan rapat rutin lintasdivisi. Selain itu, JSC juga menyediakan google form kepada masyarakat luas sebagai bahan evaluasi.

Dari hasil pengamatan penulis atas jawaban yang diberikan oleh informan pada penelitian ini, secara umum diketahui bahwa strategi pull and pass yang dilakukan oleh Divisi Komunikasi dan Divisi Marketing dalam menjalankan konsep marketing PR telah sesuai dengan konsep the Whalen 7 Steps Strategic yang merinci adanya tujuh tahap perencanaan yang baik.

91 | Vol.10 No.2 /November 2021 http://doi.org/10.31504/komunika.v10i2.4406.

(C) 2021 Jurnal Komunika:Jurnal Komunikasi dan Informatika. Semua hak cipta dilindungi undang-undang. 


\section{KESIMPULAN}

Berdasarkan hasil penelitian terhadap strategi pull and pass yang diterapkan oleh Divisi Komunikasi dan Divisi Marketing pada aplikasi Jakarta Kini, dapat disimpulkan bahwa kedua divisi ini merupakan divisi yang menjalankan peran sebagai public relations (PR) dari Jakarta Smart City. Dalam menjalankan fungsinya, kedua divisi tersebut menerapkan konsep marketing PR untuk menyosialisasikan aplikasi JAKI. Namun, dalam penerapannya, kedua divisi tersebut hanya menerapkan dua strategi dari tiga strategi marketing PR, yaitu pull and pass.

Strategi pull and pass ini dijalankan melalui pemanfaatan media sosial dengan berbagai konten, pengiriman press release ke media, pelibatan pemuka masyarakat, pengiriman email blasting hingga penyelenggaraan kegiatan online ataupun offline. Dalam pelaksanaannya, kedua divisi tersebut menerapkan konsep perencanaan marketing PR yang terdiri dari 7 tahapan perencanaan sesuai dengan teori Harris tentang the Whalen Seven Steps Strategic.

Bagi peneliti berikutnya yang ingin melanjutkan konsep penelitian marketing PR, disarankan untuk melihat konsep marketing PR secara keseluruhan pada seluruh produk yang dimiliki perusahaan. Selain itu, untuk Divisi Komunikasi dan Marketing Jakarta Smart City disarankan untuk dapat mengoptimalkan kembali upaya sosialisasi yang dilakukan kepada masyarakat agar JAKI dapat dikenal lebih luas lagi, serta dapat memilih topik webinar yang lebih fleksibel dengan narasumber yang menarik.

\section{DAFTAR PUSTAKA}

Ahyar, H., Maret, U. S., Andriani, H., Sukmana, D. J., \& Mada, U. G. (2020). Metode Penelitian Kualitatif \& Kuantitatif (Issue April). Yogyakarta: CV Pustaka Ilmu Group.

Ali, D. S. F. (2017). Marketing Public Relations Diantara Penjualan dan Pencitraan. Yogyakarta: Deepublish.

Bazaza, O. (2020). Effect of Pull and Push Marketing Strategies in the Pharmaceutical Field. International Journal of Business Marketing and Management, 5(2), 2456-4559. www.ijbmm.com

Ediraras, D. T., Rahayu, D. A., Natalina, A., \& Widya, W. (2013). Political Marketing Strategy of Jakarta Governor Election in The 2012s. Procedia - Social and Behavioral Sciences, 81(1976), 584-588. https://doi.org/10.1016/j.sbspro.2013.06.480

Hamzah, A. (2020). Metode Penelitian Studi Kasus Single Case, Instrumental Case, Multicase \& Multisite Dilengkapi Contoh Tahapan Proses dan Hasil Penelitian (N. A. Rahma (ed.)). Malang: CV. Literasi Nusantara Abadi.

Hardani, Andriani, H., Ustiawaty, J., Utami, E. F., Istiqomah, R. R., Fardani, R. A., Sukmana, D. J., \& Auliya, N. H. (2020). Metode Penelitian Kualitatif \& Kuantitatif (H. Abadi (ed.)). Yogyakarta: CV. Pustaka Ilmu Group.

Khopipah, S. (2019). Challenges Of A Dual Role Of Marketing Public Relations And Public Relations In Developing A Positive Image Of Pt Overseas Zone. 49. http://doi.org/10.21831/informasi.v49i2.28256

Kitchen, P. J. (2015). The Quarterly Review of Marketing Communications. International Journal of Advertising, 367-382. http://dx.doi.org/10.1080/02650487.1993.11104551

Leppäniemi, M. \& H. K. (2008). Mobile Marketing: From Marketing Strategy To Mobile Marketing Campaign Implementation. International Journal of Mobile Marketing, 3 No. 1.

https://www.researchgate.net/profile/Heikki-

Karjaluoto/publication/252113084_Mobile_Marketing_From_Marketing_Strategy_to_Mobile_Marketing_Ca mpaign_Implementation/links/567148a008ae2b1f87aee230/Mobile-Marketing-From-MarketingStrategy-to-Mobile-Marketing-C

Messakh, K. K., \& Fuady, M. (2017). Perencanaan Marketing Public Relations Program Net Citizen Journalism PT. Net Mediatama Indonesia. Prosiding Hubungan Masyarakat, 3. http://hdl.handle.net/123456789/23119

Ngafifi, M. (2014). Kemajuan Teknologi Dan Pola Hidup Manusia Dalam Perspektif Sosial Budaya. Jurnal Pembangunan Pendidikan: Fondasi Dan Aplikasi, 2. https://doi.org/2502-1648

Nugrahani, D. S. (2006). Strategi Komunikasi Pemasaran Melalui Periklanan Public Relations. SEGMEN Manajemen, No 1 (2006). Jurnal Manajemen \& Bisnis. http://ejournal.umpwr.ac.id/index.php/segmen/article/view/614

Papasolomou, L. \& Y. M. (2012). Social Media: Marketing Public Relations' New Best Friend. Journal of Promotion Management. http://dx.doi.org/10.1080/10496491.2012.696458

Rahman, A., Subiakto, V. U., Susanti, S., \& Purwoputro, D. (2020). The Implementation of Marketing Public Relations Strategy by the FF Luxury Watch Store on the Jakarta Based Customers. International Journal of Innovative Science and Research Technology, 5(6), 1029-1037. https://doi.org/10.38124/ijisrt20jun920

Rahmawati, S. A., Setianti, Y., \& Lukman, S. (2019). Strategi Marketing Public Relations Checo Café Resto. 8(1). Jurnal Komunika : Komunikasi dan Informatika. https://doi.org/10.31504/komunika.v10i2.4488

Suprawoto. (2018). Government Public Relations Perkembangan \& Praktik di Indonesia (1st ed.). Jakarta : Prenadamedia Group. https://books.google.co.id/books?id=ApNeDwAAQBAJ\&printsec=frontcover\&hl=id\&source=gbs_ge_summ

92 | Vol.10 No.2 /November 2021 http://doi.org/10.31504/komunika.v10i2.4406.

(C) 2021 Jurnal Komunika:Jurnal Komunikasi dan Informatika. Semua hak cipta dilindungi undang-undang. 
ary_r\&cad $=0 \# v=$ onepage \&q\&f=false

Wijaya, C. R., Waluya, B., \& Setyorini, P. D. S. (2012). Pengaruh Program Marketing Public Relations Terhadap Keputusan Berkunjung Di Pantai Pangandaran (Survei pada Wisatawan yang Berkunjung ke Destinasi Pariwisata Pantai Pangandaran). Tourism and Hospitality Essentials (THE) Journal, 2. https://doi.org/10.17509/thej.v2i2.1939

93 | Vol.10 No.2 /November 2021 http://doi.org/10.31504/komunika.v10i2.4406.

(C) 2021 Jurnal Komunika:Jurnal Komunikasi dan Informatika. Semua hak cipta dilindungi undang-undang. 